\title{
A new species of Bidessus from Anjozorobe-Angavo and a review of Malagasy Bidessus (Coleoptera, Dytiscidae)
}

\author{
Johannes BERGSTEN ${ }^{1, *}$, Tolotra RANARILALATIANA ${ }^{2} \&$ Olof BISTRÖM $^{3, * *}$ \\ ${ }^{1}$ Department of Zoology, Swedish Museum of Natural History, Box 50007, \\ SE-10405 Stockholm, Sweden. \\ ${ }^{2}$ Department of Entomology, Faculty of Sciences, Box 906, University of Antananarivo, \\ 101 Antananarivo, Madagascar. \\ ${ }^{3}$ Finnish Museum of Natural History, Zoology Unit, P.O.Box 17, \\ FI-00014 University of Helsinki, Finland. \\ *Corresponding author: johannes.bergsten@nrm.se \\ ${ }^{2}$ Email: t.ranarilalatiana@gmail.com \\ ${ }^{3}$ Email: olof.bistrom@helsinki.fi \\ ${ }^{* *}$ Contribution to the study of Dytiscidae 91

\footnotetext{
${ }^{1}$ urn:1sid:zoobank.org:author:64120AE6-1D4B-4C29-AA37-46DA7C7A26A8

${ }^{2}$ urn:1sid:zoobank.org:author:4E61E817-7646-4993-A25A-78E2B160F5B8

${ }^{3}$ urn:lsid:zoobank.org:author:2F25C707-9602-438B-BCCE-D7A9B7103BC1
}

\begin{abstract}
We review the species of Bidessus of Madagascar and describe Bidessus anjozorobe sp. nov. from material collected in Anjozorobe forest. Anjozorobe is part of the Anjozorobe-Angavo Protected Area, which is an important corridor of transition forest between typical eastern humid forests and the residual sub-humid forest of the Central Highlands. Bidessus longistriga Régimbart, 1895 and Bidessus perexiguus Kolbe, 1883 are widespread but endemic low-altitude species on Madagascar. Bidessus nesioticus Guignot, 1956 is an alpine species described from near the peak of the Ankaratra mountain massifs at $2500 \mathrm{~m}$ a.s.l. We recollected the species for the first time since its description, in Ankaratra and in a new area above $2000 \mathrm{~m}$ a.s.l. in the Andringitra mountain further south. Bidessus cf. nero Gschwendtner, 1933 is tentatively recorded for Madagascar for the first time but further studies are needed to test the status of mainland and insular populations. Bidessus apicidens Biström \& Sanfilippo, 1986 has not been recollected on Madagascar since 1970. All species are endemic to Madagascar except potentially Bidessus cf. ceratus and Bidessus cf. nero described from Uganda and the Democratic Republic of the Congo, respectively. The older records of the two non-endemic species Bidessus complicatus Sharp, 1904 and Bidessus ovoideus Régimbart, 1895 on Madagascar could not be verified.
\end{abstract}

Keywords. Aquatic insects, protected area, Madagascar, alpine, Bidessini.

Bergsten J., Ranarilalatiana T. \& Biström O. 2020. A new species of Bidessus from Anjozorobe-Angavo and a review of Malagasy Bidessus (Coleoptera, Dytiscidae). European Journal of Taxonomy 717: 1-18.

https://doi.org/10.5852/ejt.2020.720.1109 


\section{Introduction}

Bidessus Sharp, 1882 is a genus of very small-bodied diving beetles reaching only $1.3-2.3 \mathrm{~mm}$ in body length and confined to the Palaearctic and Afrotropical regions (Miller \& Bergsten 2016). The genus currently includes 50 species divided into three species groups (Nilsson \& Hajek 2020). Bidessus is most diverse in the Afrotropical region (35 spp.) where all species belong to the Bidessus sharpi species group (Biström 1985). Six species are currently known from Madagascar, four of which are endemic (Biström 1985; Biström \& Sanfilippo 1986; Rocchi 1991). The two most recently described species, Bidessus nesioticus Guignot, 1956 and Bidessus apicidens Biström \& Sanfilippo, 1986, are only known from the type material.

Anjozorobe forest is located about $90 \mathrm{~km}$ northeast of the capital Antananarivo and about $9 \mathrm{~km}$ east of Anjozorobe village. Its location is more westerly and at a higher elevation than most of the eastern humid forests in Madagascar. As such, it constitutes an important and unique transition forest between the eastern humid forests and the remaining fragments of the Central Highland sub-humid forests. Anjozorobe forest is part of the Paysage Harmonieux Protégé du Complexe Anjozorobe-Angavo since 2015, sometimes known as the 'Anjozorobe-Angavo forest corridor'. The area covers 41100 ha and is managed by the NGO Fanamby. In 2014, the first two authors surveyed water beetles in the Anjozorobe forest near Saha Forest Lodge. In a marsh at a forest opening with water visible by tramping in the vegetation we collected a series of a small dark Bidessus that we identified as a new species. The second author performed more extensive surveys of Anjozorobe in 2016 and found the species again near a stream close to the first locality.

Here, we describe the new species and review the species of Bidessus of Madagascar. We have examined a large amount of recently collected material from all over the island and provide habitus photographs, male genitalia illustrations and distribution maps of georeferenced records for all species.

\section{Material and methods}

Specimens were studied under a Leica M165C (7.3-120 × zoom range) dissection microscope. Genitals were extracted from the tip of the abdomen with a fine micropin attached to the end of a small rod. Drymounted specimens were first softened in hot water for about 10 minutes.

Line drawings of male genitalia were produced with a camera lucida attached to a Wild M11 microscope. The genitalia were temporarily positioned in glycerol for illustration and later glued onto the same mounting card as the specimen.

Habitus photographs were taken with 10X Mitutoyo plan apo microscope lens attached to a Balpro 1 bellow from Novoflex attached to a Canon EOS 7D DSLR Camera. The system was mounted onto a motorized rail (Stackshot) from Cognisys. The Stackshot rail was operated via Zerene stacker (Zerene Systems). LED lights were used as a light source and a cylinder-shaped diffuser made of white tracing paper was placed around the specimen. Photographs were taken using Canon EOS Utility in combination with Zerene Stacker and merged with the latter using the PMax algorithm.

\section{Repositories}

Material examined in this study is deposited at the following institutions:

BMNH $=$ Natural History Museum (formerly British Museum, Natural History), London, UK

CAS $\quad=$ California Academy of Sciences, San Francisco, California, USA

$\mathrm{CMM}=$ Collection of Michaël Manuel, Paris, France

DEUA $=$ Department of Entomology, Antananarivo University, Antananarivo, Madagascar 


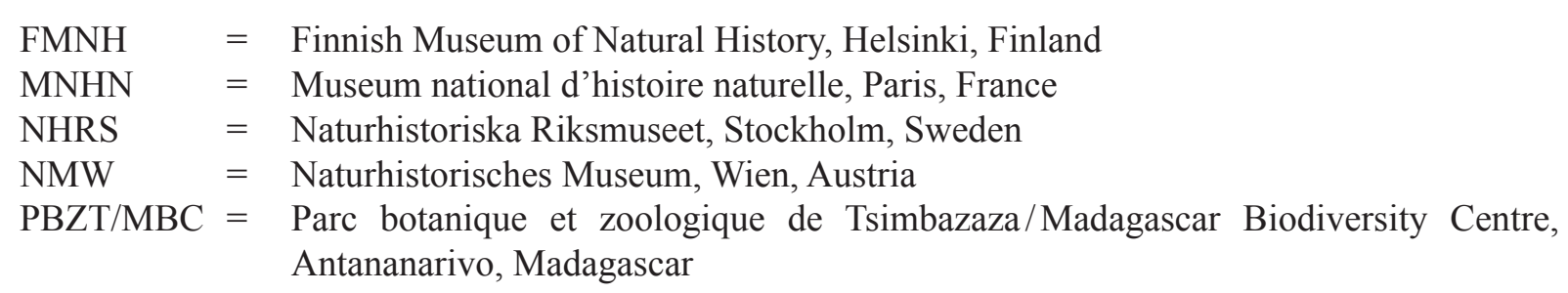

\section{Results}

\section{Key to species of Bidessus on Madagascar}

1. Elytral stria long, approximately half the length of elytron (Figs 1A, 2C) …............................... 2

- Elytral stria short, distinctly shorter than half the length of elytron (Figs 1B-D, 2A-B) ............... 3

2. Elytral stria straight (Fig. 1A); female ventrite with a deep, longitudinal furrow; female elytron posteriorly with a distinct, lateral extension (Fig. 1A) ......B. apicidens Biström \& Sanfilippo, 1986

- Elytral stria sinuate (Fig. 2C); female ventrite simple, no longitudinal furrow; female elytron posteriorly smooth, lacks extension

B. longistriga Régimbart, 1895

3. Small species (max. length $1.5 \mathrm{~mm}$ ); elytra with distinct, longitudinal, pale markings (Fig. 2B) .....

B. perexiguus Kolbe, 1883

- Larger species (length 1.5-2.0 mm); elytra predominantly dark, sometimes with minor, vague, pale markings (Figs 1B-D, 2A)

4. Frontal transverse depression of head transformed to four minor, slightly vague, tubercles (Fig. 1B) B. cf. ceratus Guignot, 1941

- Frontal transverse depression of head not transformed to small tubercles (depression laterally distinct, medially vague)

5. Head and pronotum mainly pale, testaceous (Fig. 1D) B. cf. nero Gschwendtner, 1933

- Head distinctly darker than pronotum (Figs 1C, 2A)

6. Elytral stria longer (approximately $1 / 3$ of elytron length); body shape broad (Fig. 1C); pronotum extensively pale (dark markings reduced to narrow areas close to frontal and posterior edges) (Fig. 1C); antenna pale (Fig. 1C)

B. anjozorobe sp. nov.

- Elytral stria short (less than $1 / 3$ of elytron length); body shape slender (Fig. 2A); pronotum extensively dark (pale markings reduced to quite narrow medial area, often divided into two separate spots) (Fig. 2A); antenna segments $4-11$ dark (Fig. 2A)

B. nesioticus Guignot, 1956

\section{Taxonomy}

Bidessus apicidens Biström \& Sanfilippo, 1986

Figs 1A, 3A

Bidessus apicidens Biström \& Sanfilippo, 1986: 46.

Bidessus apicidens - Rocchi 1991: 85. — Nilsson 2001: 114. — Nilsson \& Hajek 2020: 104.

\section{Diagnostic characters}

Head frontally not margined. Slightly posterior to frontal edge with a shallow, transverse depression, which medially is vague but still clearly discernible. Pronotum on disc with fine to very fine and sparse punctures (no clearly impunctate area). Pronotal striae at base strongly impressed; striae sinuate (not 


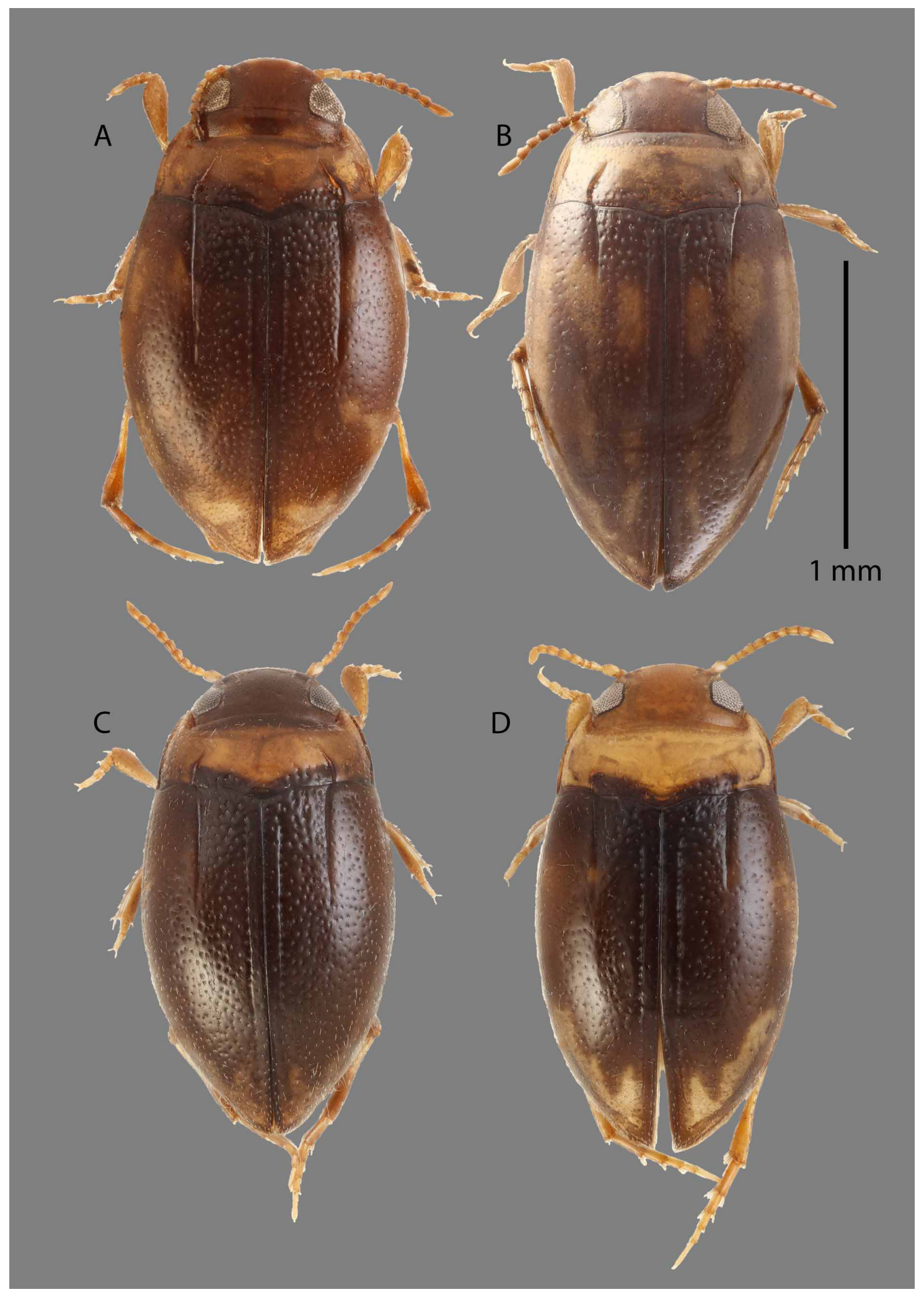

Fig. 1. Habitus photographs of Malagasy species of Bidessus Sharp, 1882. A. B. apicidens Biström \& Sanfilippo, 1986, , , paratype, http://id.luomus.fi/GL.8408 (FMNH). B. B. cf. ceratus Guignot, 1941, http://id.luomus.fi/GC.2001 (FMNH). C. B. anjozorobe sp. nov., paratype (NHRS-JLKB000025034). D. B. cf. nero Gschwendtner, 1933 (NHRS-JLKB000025032). 
angled). Basal elytral striae quite long (length of stria almost half the length of elytra). Sutural lines in part vague; frontally and especially, posteriorly the lines are transformed to rows of punctures. Moreover, posteriorly, sutural row fades away; mixed with ordinary elytra punctures. Punctures on each side of elytral striae unequal; between sutural line and elytral stria punctures quite coarse, dense but somewhat irregularly distributed; outside elytral stria punctures distinctly finer and somewhat sparser. Last ventrite of female with a distinct, medial depression which is delimited by distinct, narrow and longitudinal keels. Female elytra outline posteriorly with a small but distinct, lateral expansion (unique character in Bidessus of Madagascar). Penis in lateral view quite slender, curved but medially slightly straightened. Penis apex not distinctly extended (Fig. 3A).

Length of body $1.7 \mathrm{~mm}$.

\section{Material examined}

\section{Paratype}

MADAGASCAR • 1 क; “envir. de Moramanga” [around Moramanga]; “(Q. 1000 c.a)” [1000 m a.s.1.]; 21 Jul. 1970; N. Sanfilippo leg.; FMNH.

\section{Distribution}

Endemic species to Madagascar and only known from around Antsirabe and Moramanga (Fig. 4D). Collecting circumstances poorly known. Sampled at mid (1000 m a.s.1.) and high (1600 m a.s.1.) elevations. Only two specimens are so far known.

\section{Bidessus cf. ceratus Guignot, 1941}

Figs 1B, 3B

Bidessus ceratus Guignot, 1941: 31.

Bidessus ceratus - Guignot 1959: 257. — Biström 1985: 20. — Rocchi 1991: 85. — Nilsson 2001: 114. — Pederzani \& Rocchi 2009: 93. — Nilsson \& Hajek 2020: 104.

\section{Diagnostic characters}

Head frontally not margined. Slightly posterior to frontal edge with slight depression and anterior to it with three (sometimes four) transversely located, slight but clearly distinguishable tubercles. Pronotum on disc with a rather broad impunctate area. Pronotal striae distinct but not strongly impressed; striae angled and sinuate. Basal striae of elytra distinct but comparatively short. Sutural lines present but quite weakly developed; anteriorly they end clearly before reaching frontal edge of elytra; posteriorly they are transformed to a row of separate punctures slightly behind middle of elytra. Punctures on each side of elytral striae almost similar; fine, slightly irregularly distributed and somewhat sparse. Ventrite apically with distinct and quite dense punctures. Female with outline of elytra posteriorly smooth (minor process absent). Penis (lateral aspect) comparatively robust, evenly curved; (dorsal aspect), quite broad. Penis apex not distinctly extended (Fig. 3B).

Length of body $1.8-2.0 \mathrm{~mm}$.

\section{Material examined}

MADAGASCAR - 5 specs; "envir. de Perinet riv. Farimbany" [around Perinet, Farimbany river]; “(Q 800)" [800 m a.s.1.]; 18 Jul. 1970; N. Sanfilippo leg.; FMNH. 


\section{Distribution}

A species as tentatively defined here distributed in East Africa and Madagascar (see Biström 1985). In Madagascar only known from Moramanga and Analamazaotra NP in east central parts (Fig. 4D). However, Pederzani \& Rocchi (2009) identified seven specimens collected in southern Madagascar by Gerecke \& Goldschmidt in 2001 as B. ceratus (specimens housed at BMNH and NMW). The series, which we have not studied, was collected north of Ranopiso $\left(25.05^{\circ} \mathrm{S}, 46.67^{\circ} \mathrm{E}\right)$ near the southern part of Andohahela NP and ca $35 \mathrm{~km}$ west of Taolanaro.

\section{Collecting circumstances}

According to label information sampled at $800-1000 \mathrm{~m}$ a.s.l.

\section{Taxonomic observation}

Bidessus ceratus is described from Uganda in eastern continental Africa. When the B. sharpi species group was revised (Biström 1985), specimens from Madagascar were considered to belong to this species. There are, however, features, which indicate the existence of a separate species in Madagascar. No fresh specimens in ethanol are at present available for DNA analyses and accordingly the earlier interpretation is retained.

Bidessus longistriga Régimbart, 1895

Figs 2C, 3G

Bidessus longistriga Régimbart, 1895: 79.

Bidessus longistriga - Alluaud 1900: 59. — Zimmermann 1920: 54. — Guignot 1959: 254. — Biström 1985: 7. — Rocchi 1991: 85. — Nilsson 2001: 115. — Pederzani \& Rocchi 2009: 93. — Nilsson \& Hajek 2020: 104.

\section{Diagnostic characters}

Head frontally not margined but provided with a shallow, transverse depression slightly posterior to anterior edge of head (between eyes). Pronotum on disc with a broad impunctate area or with a few fine punctures, distinctly sparser than punctures at frontal and posterior edge. Pronotal striae at base deeply impressed. Pronotal striae with a distinct angle (not smoothly curved). Basal striae of elytra long. Sutural lines distinct; anteriorly and posteriorly lines fade away; transformed to row of punctures. Punctures on both side of basal striae of unequal size; distinctly coarser on inner side. Apical sternite with fine, slightly irregular punctures. Female with outline of elytra posteriorly smooth (minor extension absent). Penis in lateral view slender, curved but medially somewhat straightened. Penis apex not distinctly extended (Fig. 3G).

Length of body $1.6-1.8 \mathrm{~mm}$.

\section{Material examined}

283 specimens (BMNH, NHRS, NMW, PBZT/MBC, DEUA) from provinces Antsiranana, Mahajanga, Toliara, Fianarantsoa and Toamasina (see Supplementary File 1).

\section{Distribution}

Endemic species to Madagascar but widely distributed on the island in lowland areas below $800 \mathrm{~m}$ a.s.l. (Fig. 4A). 


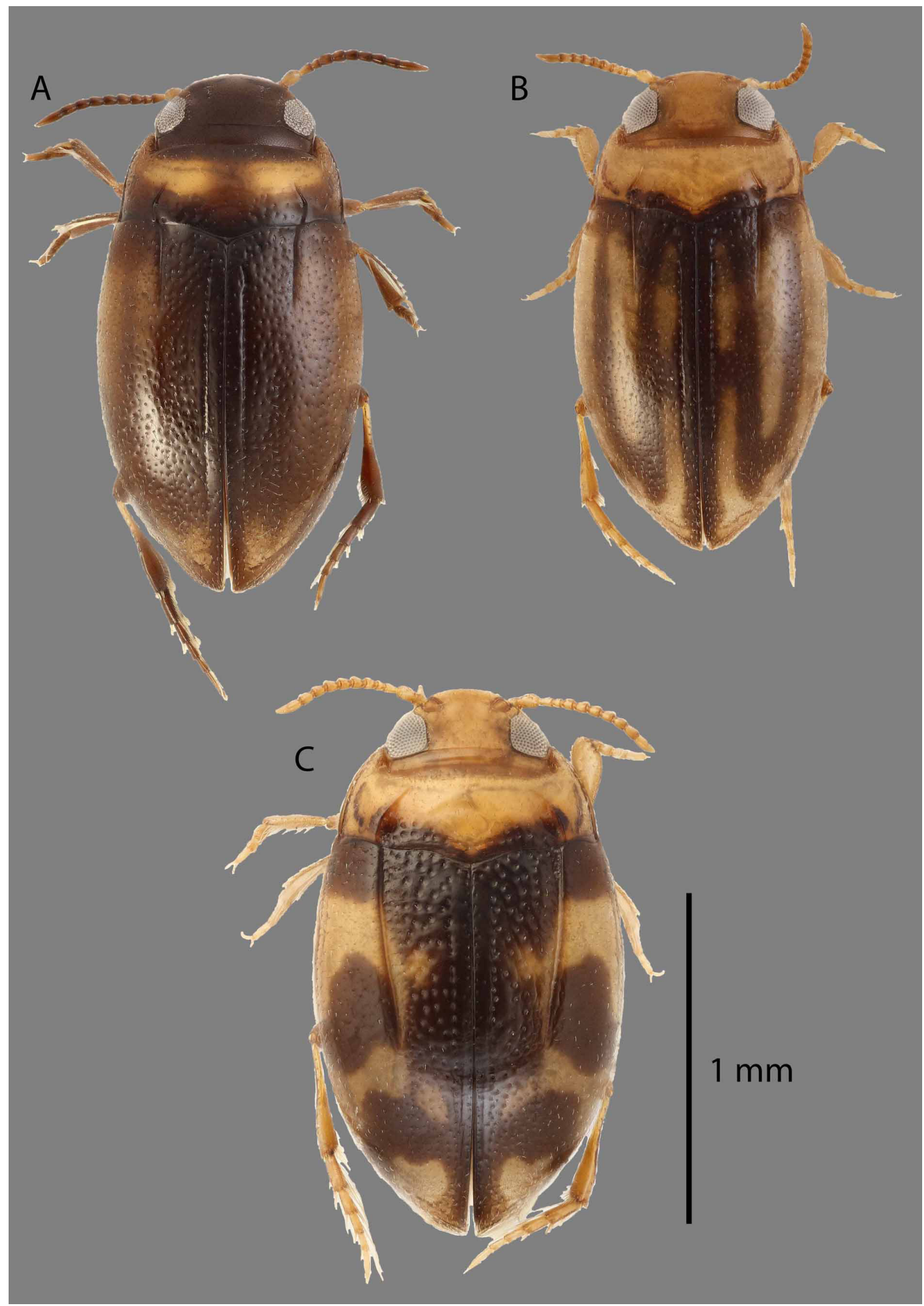

Fig. 2. Habitus photographs of Malagasy species of Bidessus Sharp, 1882. A. B. nesioticus Guignot, 1956 (NHRS-JLKB000025031). B. B. perexiguus Kolbe, 1883 (NHRS-JLKB000025029). C. B. longistriga Régimbart, 1895 (NHRS-JLKB000025028). 


\section{Collecting circumstances}

An apt flier that can be collected at light. At low altitudes on both east and west coast, found in a variety of stagnant waters (rice fields, ponds, pools in riverbeds), and in slow-flowing parts of rivers and canals. Often occurs sympatrically with $B$. perexiguus.

Bidessus anjozorobe sp. nov.

urn:1sid:zoobank.org:act:C6F11BD1-C6DC-41B6-8994-35C58E062999

Figs $1 \mathrm{C}, 3 \mathrm{C}$

\section{Diagnostic characters}

Head slightly posterior to frontal edge with a shallow, transverse depression, which medially is vague. Pronotum discally with broad area with fine, sparse and irregular punctures. Pronotal striae at base strongly impressed; angled (not smoothly curved). Basal striae of elytra medium long, straight (close to base, strongly curved outwards); at base quite strongly impressed. Sutural lines close to frontal edge of elytra distinct; posteriorly lines gradually fade away. Female with outline of elytra posteriorly smooth (minor process absent). Penis in lateral view curved, medially slightly straightened. Penis apex with a long and slender extension (Fig. 3C), a feature which separates B. anjozorobe from all other Bidessus species known from Madagascar. Considering morphology $B$. anjozorobe most resembles $B$. perrinae Biström, 1985 thus far known from Angola. The two species are separated as follows: elytra almost unicolored dark, black to dark piceous in B. anjozorobe while distinctly bicolored in B. perrinae, elytra being brownish to dark ferrugineous with distinct testaceous markings. Furthermore, body slightly larger and more robust in $B$. anjozorobe than in $B$. perrinae (length of body $1.6 \mathrm{~mm}$ ). See original description in Biström (1985).

\section{Etymology}

Named after the type locality Anjozorobe forest, part of the Anjozorobe-Angavo protected area. The epithet is a noun in apposition (ICZN 11.9.1.2).

\section{Type material}

\section{Holotype}

MADAGASCAR -1 ; ; Antananarivo former province, Analamanga region, $10 \mathrm{~km}$ E of Anjozorobe, Anjozorobe-Angavo protected area, marsh next to the stream in Saha forest; $18.4128^{\circ} \mathrm{S}, 47.9439^{\circ} \mathrm{E}$; 1320 m a.s.1.; 23 Nov. 2014; J. Bergsten, R. Bukontaite, S. Holmgren, J.H. Randriamihaja and T. Ranarilalatiana leg.; collecting event MAD14-78; forest marsh; NHRS-JLKB000025033.

\section{Paratypes}

MADAGASCAR • $1 \mathrm{spec}$;; same collecting data as for holotype; NHRS-JLKB000025034 27 specs (preserved in ethanol); same collecting data as for holotype; NHRS-JLKB000025027 - 5 specs; same collecting data as for holotype; FMNH $\bullet 5$ specs; same collecting data as for holotype; BMNH $\bullet 5$ specs; same collecting data as for holotype; PBZT/MBC - 5 specs; same collecting data as for holotype; DEUA 1 1 ; Antananarivo former province, Analamanga region, $10 \mathrm{~km}$ E of Anjozorobe, Anjozorobe Angavo protected area, Antsahabe, circuit bamboo; $18.41266^{\circ} \mathrm{S}, 47.9438^{\circ} \mathrm{E} ; 1341$ m a.s.1.; 5 Apr. 2016; T. Ranarilalatiana leg.; collecting event MAD16-40; marsh and stream pool; NHRS-JLKB000065489 • 1 +; same collecting data as for preceding; NHRS-JLKB000065490.

\section{Type locality}

Madagascar, Antananarivo, Analamanga, Anjozorobe-Angavo Protected Area, Saha forest $\left(18.4128^{\circ} \mathrm{S}\right.$, 47.9439 E) (Fig. 5). 


\section{Description}

\section{Male}

Body. Length 1.7-1.8 mm. Dorsal aspect as in Fig. 1C. Angle between pronotum and elytra indistinct.

HeAD. Dark brown to dark piceous. Frontally between eyes not margined. Slightly posterior to frontal edge with a shallow, transverse depression, which medially is vague. Shiny although covered with fine, slightly indistinct reticulation; meshes when distinguished are isodiametric. Posterior to cervical line reticulation indistinct; surface is shagreened. With fine, sparse and somewhat irregular punctures. Posterior to cervical line impunctate. Antenna with basal segments 1-4 pale, testaceous; segments 5-11 darker; brown to piceous.

Pronotum. Broadest at posterior corners. Sides posteriorly straight; anteriorly clearly curved inwards. Bright testaceous; anteriorly and between striae with narrow blackish to dark brown, transverse area. At posterior corners with vague, darker spots. Discally with broad area with fine, sparse and irregular punctures. At pronotal edges punctures coarser and denser. Shiny, not reticulated.

ELYTRA. Black to dark piceous; apically with a vague, paler area. Basal striae medium long and straight (close to frontal edge strongly curved outwards for a short distance). Sutural lines close to frontal edge of elytra, distinct; posteriorly lines gradually fade away. Punctures fine to rather fine, somewhat sparse and with slightly irregular distribution. On each side of elytral stria, punctures of almost equal size and density. Towards apical region punctures become slightly finer. In frontal half of elytra with a lateral row of slightly irregular punctures. Row of punctures form a shallow but clearly discernible furrow which in posterior half disappears. Narrow area between furrow and epipleuron pale brownish and with finer and sparser punctures. Shiny, not reticulated. Epipleura pale brownish.

Ventral asPect. Pronotum testaceous, with lateral edges narrowly blackish. Metathorax, metacoxal plates and abdomen blackish to dark piceous. Rather shiny, reticulation absent. Punctures distributed as follows: metathorax medially with two rows of fine punctures and at frontal and lateral edge with a single row. Metacoxal plates medially with a few scattered punctures and at inner margin of metacoxal lines with a row of punctures. Abdomen at base with irregular coarse punctures and ventrite in apical half with dense, quite coarse punctures. Otherwise ventral aspect almost impunctate.

Legs. Testaceous to brownish. Protarsi slightly enlarged; mesotarsi slender.

Male genitalia. Fig. 3C.

\section{Female}

Similar to male but protarsi not enlarged, narrower than in male.

\section{Distribution}

Endemic to Madagascar and only known from the type locality in Anjozorobe forest, Central Highlands (Fig. 4C).

\section{Collecting circumstances}

The type locality is a vegetation rich marsh in a forest glade at an elevation of $1320 \mathrm{~m}$ a.s.l. (Fig. 5). Small water pools were visible at the edges of the marsh during the visit at the end of November 2014 but mostly derived through stamping in the vegetation. Anjozorobe-Angavo forest corridor with its westerly location is a higher elevation forest and represents a transition type between typical eastern humid forest and sub-humid high plateau forest. 

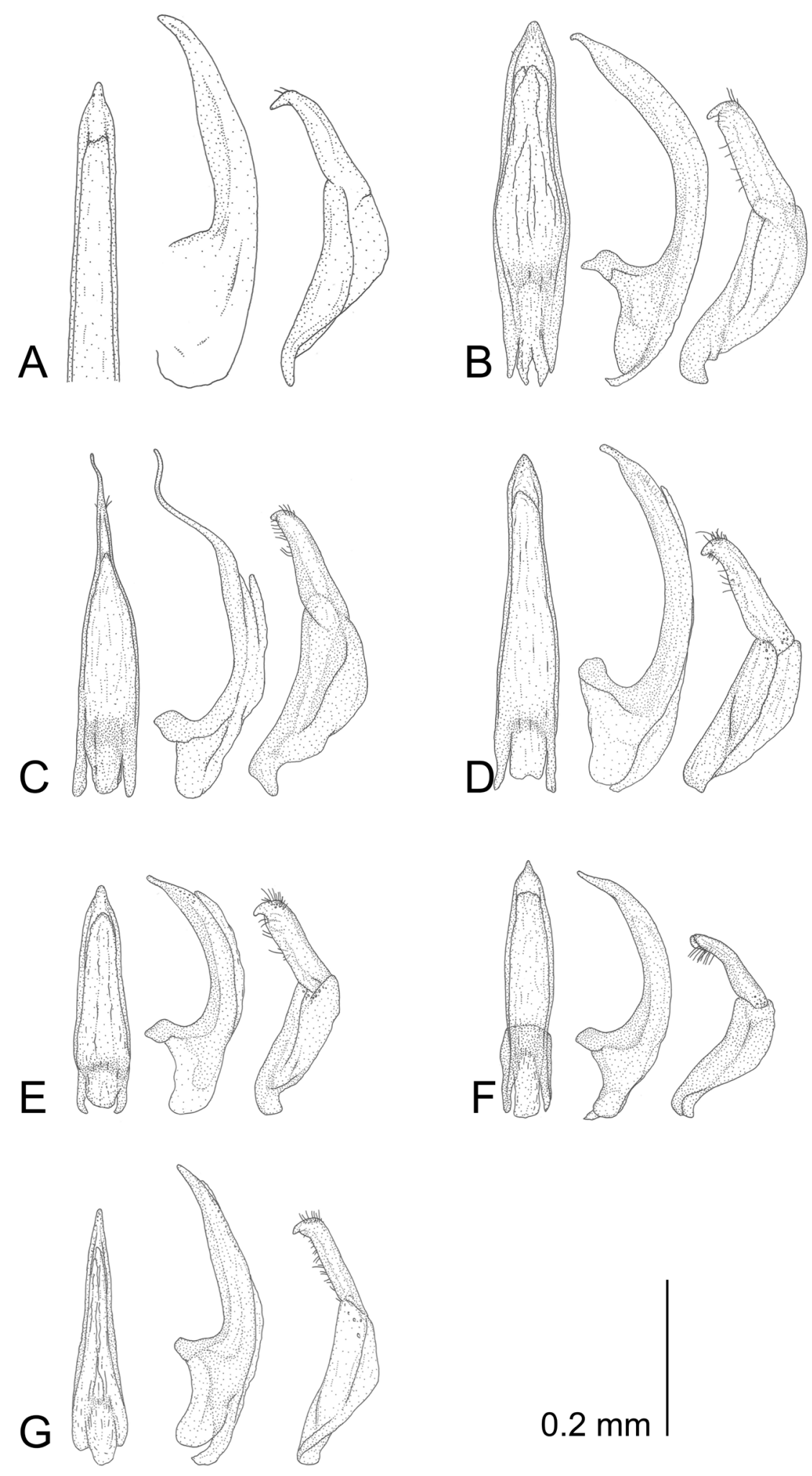

Fig. 3. Male genitalia of the Malagasy species of Bidessus Sharp, 1882. For each subpanel from left to right penis in dorsal view, penis in lateral view and paramere in lateral view. A. B. apicidens Biström \& Sanfilippo, 1986. B. B. cf. ceratus Guignot, 1941. C. B. anjozorobe sp. nov. D. B. cf. nero Gschwendtner, 1933. E. B. nesioticus Guignot, 1956. F. B. perexiguus Kolbe, 1883. G. B. longistriga Régimbart, 1895. 
Bidessus cf. nero Gschwendtner, 1933

Figs 1D, 3D

Bidessus nero Gschwendtner, 1933: 86.

Bidessus nero - Biström 1985: 18. — Nilsson 2001: 115. — Nilsson \& Hajek 2020: 104.

Bidessus unicolor (Guignot, 1946) - Guignot 1959: 255.

\section{Diagnostic characters}

Head frontally not margined; provided with a slight depression slightly posterior to anterior edge of head (between eyes); frontal depression is medially broadly vague and indistinct. Pronotum on disc with a broad impunctate area. Pronotal striae at base not deeply impressed, distinctly angled and not smoothly curved. Basal striae of elytra medium long and distinct. Anteriorly sutural lines of elytra disappear abruptly a short distance before reaching frontal edge; posteriorly lines fade away long before reaching apex. Elytra with punctures on each side of basal striae of equal size and density (rather fine, sparse and slightly irregular). Apical ventrite with rather fine, slightly sparse punctuation. Female with outline of elytra posteriorly smooth (minor process absent). Penis in lateral view quite slender and evenly curved; apex distinct (also slightly curved). Penis apex not distinctly extended (Fig. 3D).

Length of body $1.5-1.9 \mathrm{~mm}$.

\section{Material examined}

MADAGASCAR - 1 j; Fianarantsoa former province, Amoron'i Mania region, $3 \mathrm{~km}$ south of Ambalamanakana next to RN7, Ankazomivady forest; $20.7722^{\circ} \mathrm{S}, 47.1809^{\circ} \mathrm{E} ; 1700 \mathrm{~m}$ a.s.1.; 1 Nov. 2014; J. Bergsten, T. Ranarilalatiana and S. Holmgren leg.; collecting event MAD14-02; hygropetric rocks and marsh with vegetation; NHRS-JLKB000025032 5 specs (preserved in ethanol); same collection data as for preceding; NHRS-JLKB000025024 1 spec.; same collection data as for preceding; FMNH • 1 spec.; same collection data as for preceding; $\mathrm{PBZT} / \mathrm{MBC} \bullet 1 \mathrm{spec}$. (preserved in ethanol); Fianarantsoa former province, Matsiara Ambony region, Ranomafana NP, $500 \mathrm{~m}$ from the road at Vohiparara village; $21.2397^{\circ} \mathrm{S}, 47.3774^{\circ}$ E; $1110 \mathrm{~m}$ a.s.1.; 3 Nov. 2014; J. Bergsten, T. Ranarilalatiana and S. Holmgren leg.; collecting event MAD14-10; small forest lake with floating margins of vegetation; NHRSJLKB000025025 - $1 \mathrm{spec}$.; Toamasina former province, Alaotra Mangoro region, $6 \mathrm{~km} \mathrm{~W}$ of Moramanga, Betsabora river by RN2 near Antsampanana village; $18.9247^{\circ} \mathrm{S}, 48.1828^{\circ} \mathrm{E} ; 900 \mathrm{~m}$ a.s.1.; 24 Nov. 2014; J. Bergsten, J.H. Randriamihaja and T. Ranarilalatiana leg.; collecting event MAD14-81; river with side pools; NHRS-JLKB000025026 2 specs; Fianarantsoa former province, ca 9 km SW Ivato, Bemanta (inselberg); $20^{\circ} 40^{\prime} 00^{\prime \prime} \mathrm{S}, 4^{\circ} 07^{\prime} 41.5^{\prime \prime} \mathrm{E}$; $1531 \mathrm{~m}$ a.s.1.; 18 May 2016; Ramahandrison and Manuel leg.; wide and calm portion of small river; CMM 16 specs; Fianarantsoa former province, along road N7 between Ambositra and Fianarantsoa, ca $3.5 \mathrm{~km} \mathrm{~S}$ of Ambalamanakana; 20 46'33" S, 47 $10^{\prime} 53^{\prime \prime} \mathrm{E}$; 1702 m a.s.1.; 19 May 2016; Ramahandrison and Manuel leg.; large pond with Nymphaeaceae and surrounding peat bog with Sphagnum and Drosera; CMM - 13 specs; Fianarantsoa former province,

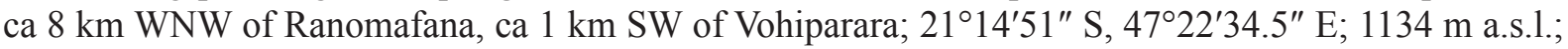
29 Dec. 2017; Ramahandrison and Manuel leg.; small marsh, very shallow, with small Poaceae and Cyperaceae, along slowly flowing stream; CMM.

\section{Distribution}

First record from Madagascar and here recorded from Ranomafana NP, near Ambalamanakana and Ivato along RN7 and near Moramanga (Fig. 4C). As tentatively defined here, the species is distributed in central and east Africa and Madagascar (see Biström 1985; Nilsson \& Hajek 2020). 

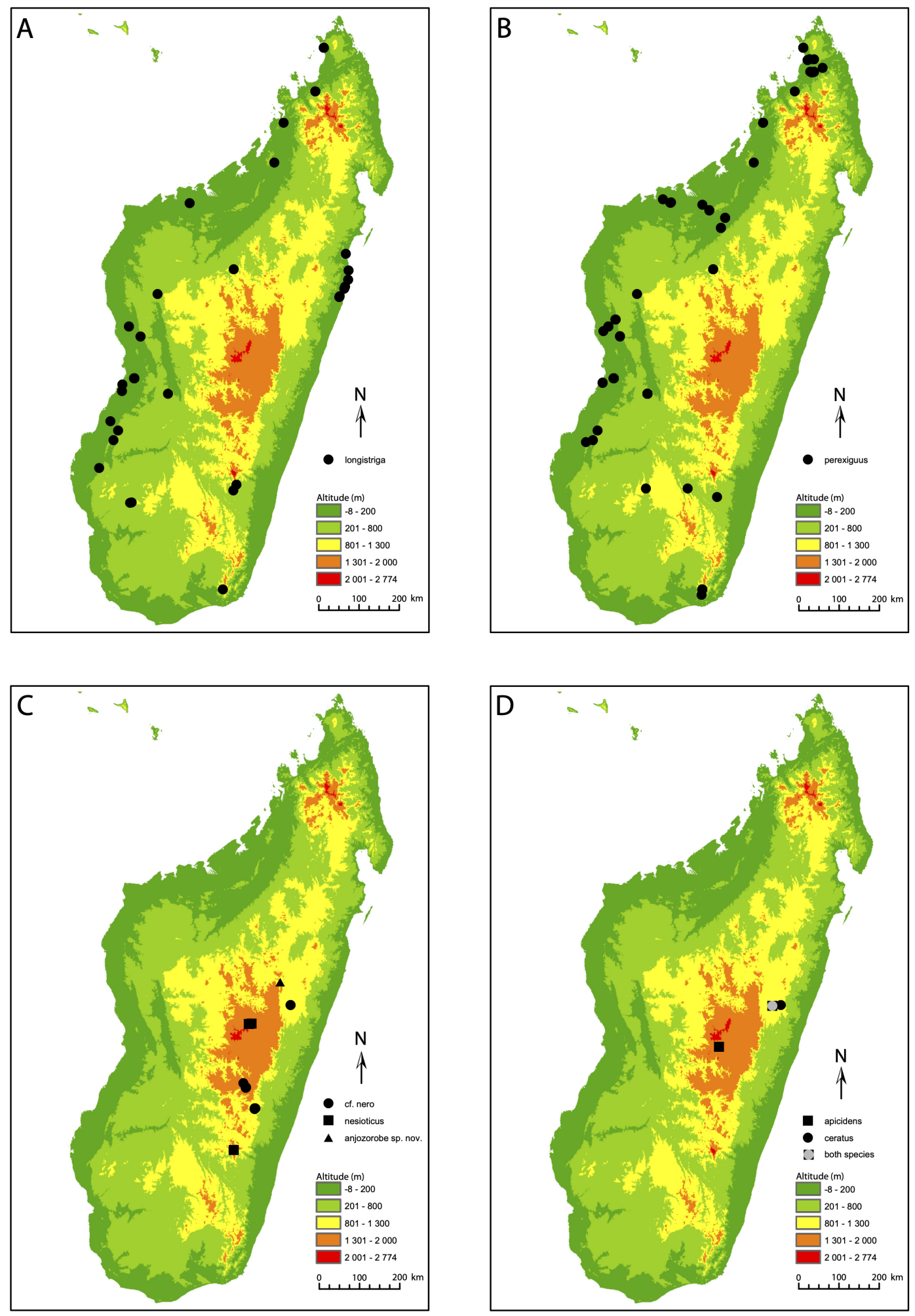

Fig. 4. Distribution maps of the Malagasy species of Bidessus Sharp, 1882. A. B. longistriga Régimbart, 1895. B. B. perexiguus Kolbe, 1883. C. B. cf. nero Gschwendtner, 1933 (circle), B. nesioticus Guignot, 1956 (square), B. anjozorobe sp. nov. (triangle). D. B. apicidens Biström \& Sanfilippo, 1986 (square), B. cf. ceratus Guignot, 1941 (circle). 


\section{Collecting circumstances}

On Madagascar found at elevations between 900-1700 m a.s.l. The localities are characterized by being vegetation-rich stagnant waters, a pool next to a river, a pond/marsh and small lake with floating vegetation edges. Semi-open to open landscapes.

\section{Taxonomic observation}

Further study on molecular level may reveal that $B$. cf. nero in Madagascar is in fact a separate species.

Bidessus nesioticus Guignot, 1956

Figs 2A, 3E

Bidessus nesioticus Guignot, 1956: 77.

Bidessus nesioticus - Biström 1985: 35. — Rocchi 1991: 85. — Nilsson 2001: 115. — Nilsson \& Hajek 2020: 104.

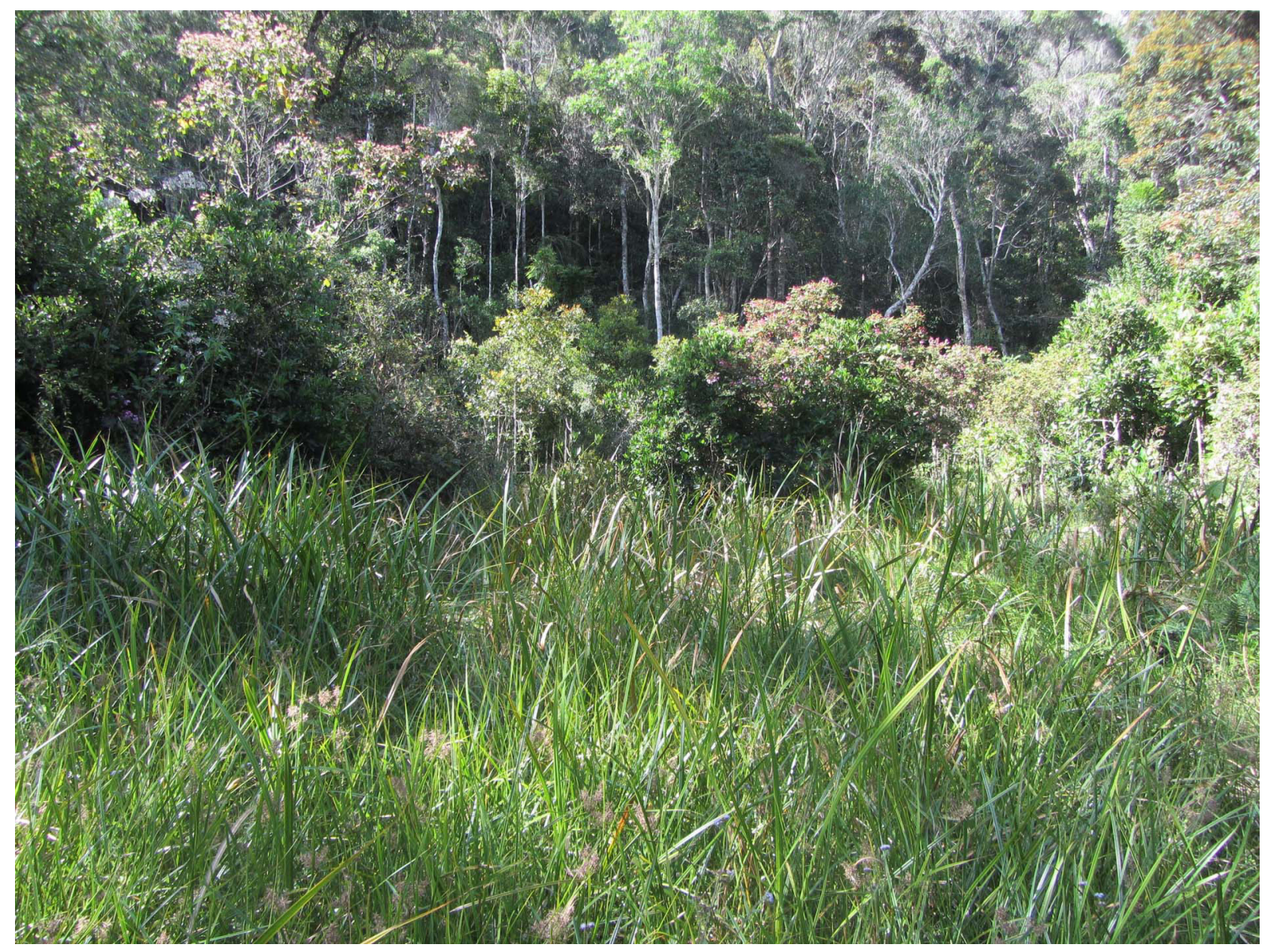

Fig. 5. Type locality [MAD14-78] for Bidessus anjozorobe sp. nov. in Anjozorobe forest in AnjozorobeAngavo protected area on the Central Highlands. A glade in the rainforest with marsh vegetation. Multiple individuals of Bidessus anjozorobe sp. nov. were found by tramping in the vegetation at the edges of the marsh. 


\section{Diagnostic characters}

Head frontally not margined; somewhat posterior to frontal edge (between eyes) with a transverse depression which becomes indistinct medially. Pronotum on disc with a quite broad, almost impunctate area (fine scattered punctures discernible). Pronotal striae quite deeply impressed, distinctly angled (striae not smoothly curved). Basal striae of elytra moderately long, not deeply impressed. Sutural lines distinct; posteriorly they fade away a short distance before apex; anteriorly, distinguished almost up to posterior edge of pronotum. Size of punctures on each side of basal striae rather fine, almost of equal size. Apical ventrite with fine, quite sparse punctures. Female with posterior outline of elytra smooth (no minor extension). Penis, dorsal aspect comparatively broad and short; in lateral aspect curved. Apex of penis not distinctly extended (Fig. 3E).

Body length 1.6-1.7 mm. Shiny, dorsally not microsculptured (frontally on head fragments of reticulation distinguished). General color of body dark piceous to blackish. Pronotum discally on each side with a well-delimited, testaceous spot. Elytra with vague, slightly paler, longitudinal markings. Apex of elytra slightly paler. Base of antenna and legs in part slightly paler.

\section{Material examined}

\section{Holotype}

MADAGASCAR • 1 つ̊; Ankaratra, Tsiafajavona; 2500 m a.s.1.; Jun. 1947; J. Millot leg.; MNHN. [Note that Biström (1985) during his revision of the group, was unable to locate this holotype that we have since rediscovered.]

\section{Additional material}

MADAGASCAR • 1 spec.; Antananarivo former province, Vakinankaratra region, Manjakatompo Stn Forestière, Anosiarivo; $19.34489^{\circ} \mathrm{S}, 047.30414^{\circ} \mathrm{E} ; 2073 \mathrm{~m}$ a.s.1.; 24 Jan. 2012; T. Ranarilalatiana and J.H. Randriamihaja leg.; collecting event MAD-MJK12-13; lake near source; NHRS-JLKB000025031 - 20 specs (preserved in ethanol); same collection data as for preceding; NHRS-JLKB000024967 • 5 specs; same collection data as for preceding; FMNH -5 specs; same collection data as for preceding; $\mathrm{PBZT} / \mathrm{MBC} \cdot 5$ specs; same collection data as for preceding; BMNH $\bullet 5$ specs; same collection data as for preceding; DEUA 18 specs (preserved in ethanol); Fianarantsoa former province, Haute Matsiatra region, Andringitra NP, lake north east of camp 3; $22.17373^{\circ} \mathrm{S}, 46.9016^{\circ} \mathrm{E} ; 2026 \mathrm{~m}$ a.s.1.; 2 Dec. 2013; J.H. Randriamihaja and T. Ranarilalatiana leg.; collecting event MAD13-33; small lake in open area; NHRS-JLKB000025023 • 5 specs; same collection data as for preceding; PBZT/MBC • 4 specs; Fianarantsoa former province, Ankaratra massif, ca $2.7 \mathrm{~km}$ WNW of Manjakatompo; $19^{\circ} 21^{\prime} 57^{\prime \prime} \mathrm{S}$, 47²18'22.5" E; 1814 m a.s.1.; 19 Dec. 2017; Ramahandrison and Manuel leg.; large grassy temporary pond, beneath slope with pine trees, with Conchostraca crustaceans; CMM.

\section{Distribution}

Endemic species to Madagascar and known from the Ankaratra and Andringitra mountain massifs in central Madagascar (Fig. 4C).

\section{Collecting circumstances}

This is a high-elevation alpine species on Madagascar, only known from above $1800 \mathrm{~m}$ altitude. The type material was collected at $2500 \mathrm{~m}$ altitude near the Ankaratra peak Tsiafajavona in 1947. TR and Jacquelin Herisahala Randriamihaja found it in an overflooded glade near a source in 2012 at a slightly lower elevation on Ankaratra (2073 m) (Fig. 6A). Additionally, they discovered the species for the first time outside Ankaratra in a small lake with vegetation at $2026 \mathrm{~m}$ elevation in Andringitra NP further south in 2013 (Fig. 6B). A few specimens were collected in a clearwater grassy pond as low as $1814 \mathrm{~m}$ in the Ankaratra mountain by A.T. Ramahandrison and M. Manuel in 2017. 
Bidessus perexiguus Kolbe, 1883

Figs $2 \mathrm{~B}, 3 \mathrm{~F}$

Bidessus perexiguus Kolbe, 1883: 407.

Bidessus perexiguus - Régimbart 1895: 82. — Alluaud 1900: 60. —Zimmermann 1920: 56. — Guignot 1959: 260. — Biström 1985: 28. — Rocchi 1991: 85. — Nilsson 2001: 115. — Pederzani \& Rocchi 2009: 93. — Nilsson \& Hajek 2020: 105.

\section{Diagnostic characters}

Head frontally not margined but provided with a shallow, transverse depression which medially is indistinct. Pronotum discally with a broad area with fine and sparse punctures; distinctly sparser than punctures at frontal and posterior edge. Pronotal striae at base deeply impressed. Pronotal striae with a distinct angle (not smoothly curved). Basal striae of elytra rather short. Sutural lines distinct; anteriorly and posteriorly lines fade away; anteriorly lines transformed to a short row of a few punctures. Punctures on both side of basal striae fine, sparse and of equal size. Apical ventrite with a few fine, slightly irregular punctures. Female with outline of elytra posteriorly smooth (minor extension absent). Penis in lateral view slender, almost evenly curved. Penis apex slightly extended (Fig. 3F).

Length of body $1.4-1.5 \mathrm{~mm}$.

\section{Material examined}

478 specimens (NHRS, CAS, NMW, PBZT/MBC, BMNH, DEUA) from provinces Antsiranana, Mahajanga, Toliara and Fianarantsoa (see Supplementary File 1).

\section{Distribution}

Endemic species to Madagascar but as B. longistriga widely distributed on the island in lowland areas below 800 m a.s.l. (Fig. 4B).

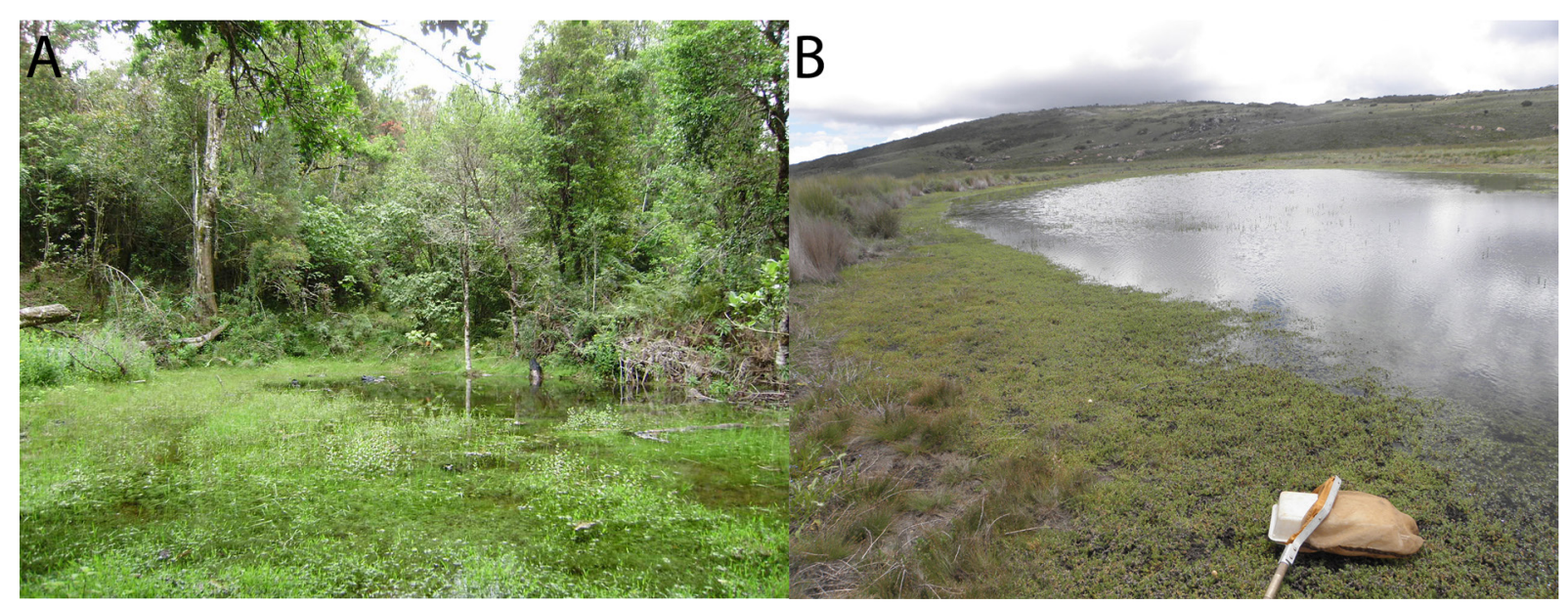

Fig. 6. Two localities of the high-altitude alpine species Bidessus nesioticus Guignot, 1956 previously known but from the type locality at $2500 \mathrm{~m}$ a.s.l. near the peak Tsiafajavona of Ankaratra mountain. A. A glade swamped by water from a source [MAD-MJK12-13] in Manjakatompo Ankaratra, 2070 m a.s.l. B. The new location [MAD13-33] of Bidessus nesioticus Guignot, 1956 at a pond in the alpine zone $2030 \mathrm{~m}$ a.s.1. on the Andringitra mountain massif in Andringitra NP. 


\section{Collecting circumstances}

An apt flier that can be collected at light. At low altitude it can occur in a variety of mainly stagnant habitats such as eutrophied ponds, pools in dried out riverbeds, even water-filled wheel tracks. Often occurs sympatrically with $B$. longistriga, at least in western parts of Madagascar.

\section{Discussion}

Guignot (1959) gave records of Bidessus complicatus Sharp, 1904 and Bidessus ovoideus Régimbart, 1895 (the former as B. brevistriga Régimbart, 1906, a junior synonym) from the Manjakatompo Ankaratra massif, Madagascar (December.1951; leg. P. Benoist). However, during his revision Biström (1985) was unable to verify either of these records or the presence of either of the two species on Madagascar. We have visited Manjakatompo Ankaratra several times but have not collected these species. We consider their occurrence on Madagascar dubious until they can be verified with specimens and have not included them in the key. With these two species excluded and the new species herein described added, the fauna of Bidessus of Madagascar comprises seven currently known species. However, also among these there remain uncertainties as to endemicity as well as current status. Whether Madagascan individuals of what is herein referred to as Bidessus cf. ceratus and Bidessus cf. nero belong to the same taxa as the mainland populations of the named species, or if they are closely related but endemic island taxa, needs to be further investigated. Finally, Bidessus apicidens was described from two specimens collected by N. Sanfilippo in July 1970 and, to our knowledge, has never been found again despite having been collected in easily accessible areas (around Moramanga and Antsirabe). The seasonal variation of adult abundance (their phenology, largely unknown for the species treated here) could possibly be part of an explanation as Sanfilippo's visit in the middle of the dry austral winter contrasts with most of our own past fieldwork carried out during, or at the limit of, the rainy season. However, another possibility is that the habitats visited by Sanfilippo may be largely destroyed today. Madagascar has experienced a rapid pace of deforestation in the second half of the $20^{\text {th }}$ and the beginning of the $21^{\text {st }}$ century, and the area around Moramanga was identified as one of the hotspots of deforestation between 1973-2014 by Vieilledent et al. (2018). Many endemic diving beetle species on Madagascar are only found in aquatic habitats in intact native forests and are severely threatened by deforestation (Bergsten et al. in press; Ranarilalatiana 2020). Knowledge of the identity and distribution of aquatic endemic taxa is therefore urgently needed as it provides the foundation to identify Key Biodiversity Areas with relevance for threatened freshwater diversity on Madagascar.

\section{Acknowledgements}

We are grateful to the Ministère de l'Environment, de l'Écologie et des Fôrets for authorising the fieldwork over several years for this and other studies on water beetles as well as Madagascar National Parks and NGO Fanamby for the work at Anjozorobe-Angavo protected area. We thank Antoine Mantilleri (MNHN), Manfred Jäch (NMW), David H. Kavanaugh (CAS) and Michaël Manuel for making additional material, records and types available for our study. We finally thank Jacquelin Herisahala Randriamihaja, Rasa Bukontaite, Sandra Holmgren and Niklas Apelqvist for participation in fieldwork.

\section{References}

Alluaud C. 1900. Liste des insectes coléoptères de la région malgache. In: Grandidier A. (ed.) Histoire physique, naturelle et politique de Madagascar volume 21, Histoire naturelle des Coléoptères, tome I, texte, $1^{\text {er }}$ partie: 56-76. Imprimerie nationale, Paris. https://doi.org/10.5962/bhl.title.1599

Bergsten J., Manuel M., Ranarilalatiana T., Ramahandrison A.T. \& Hájek J. In press. Dytiscidae, diving beetles, tsikovoka. In: Goodman S.M. (principal editor). The Natural History of Madagascar, $2^{\text {nd }}$ Ed. The University of Chicago Press, Chicago. 
Biström O. 1985. A revision of the species group B. sharpi in the genus Bidessus (Coleoptera, Dytiscidae). Acta Zoologica Fennica 178: 1-40.

Biström O. \& Sanfilippo N. 1986. Bidessus apicidens sp. n., and faunistic notes on the genus from Africa (Coleoptera, Dytiscidae). Annales Entomologici Fennici 52: 46-47.

Gschwendtner L. 1933. Neue Schwimmkäfer aus Belgisch Kongo. IV. Teil. Revue de Zoologie et botanique africaines 23: 84-95.

Guignot F. 1941. Description de nouveaux Dytiscidae d'Afrique. Bulletin de la Société d'Étude des Sciences naturelles de Vaucluse 11 (3-4) (1940): 31-39.

Guignot F. 1956. Contribution à la connaissance de la faune dystiscidienne Malgache. Le Naturaliste malgache 8: 75-80.

Guignot F. 1959. Revision des Hydrocanthares d'Afrique (Coleoptera: Dytiscoidea). Première Partie. Annales de Musée royal du Congo Belge, Tervuren: Sciences zoologiques 70: 1-313.

Kolbe H.J. 1883. Über die madagascarischen Dytisciden des Königl. entomologischen Museums zu Berlin. Archiv für Naturgeschichte 49 (1): 383-427.

Miller K.B. \& Bergsten J. 2016. Diving Beetles of the World. Systematics and Biology of the Dytiscidae. Johns Hopkins University Press, Baltimore.

Nilsson A.N. 2001. Dytiscidae (Coleoptera). World Catalogue of Insects 3: 1-395.

Nilsson A.N. \& Hajek J. 2020. A World Catalogue of the Family Dytiscidae, or the Diving Beetles (Coleoptera, Adephaga) Version 1.I.2020. Electronic and updated version of Nilsson A.N. (2001). Dytiscidae. In: World Catalogue of Insects: 1-395. Available from www.waterbeetles.eu [accessed 5 Sep. 2020].

Pederzani F. \& Rocchi S. 2009. On some Madagascan Hydradephaga of The Natural History Museum, London, with the descriptions of five new species of Dytiscidae (Coleoptera Haliplidae, Dytiscidae, Noteridae). Atti dell'Accademia Roveretana degli Agiati, Contributi della Classe di Scienze Matematiche, Fisiche e Naturali (8) 8B (258) (2008): 81-100.

Ranarilalatiana T. 2020. Diversité de Copelatus Erichson, 1832 (Coleoptera, Dytiscidae) de Madagascar et des Coléoptères Adephaga aquatiques dans les vestiges forestiers du Haut Plateau Central particulièrement sur les aires protégées de Manjakatompo Ankaratra, d'Ambohitantely et d'AnjozorobeAngavo. Ph.D. thesis, Université d'Antananarivo, Madagascar.

Régimbart M. 1895. Révision des Dytiscidae et Gyrinidae d'Afrique, Madagascar et îles voisines. Mémoires de la Société entomologique de Belgique 4: 1-244.

Rocchi S. 1991. Contributo alla conoscenza degli Haliplidae e dei Dytiscidae del Madagascar con descrizione di due nuove specie (Coleoptera). Frustula Entomologica (Nuova Serie) 14: 71-89.

Vieilledent G., Grinand C., Rakotomalala F., Ranaivosoa R., Rakotoarijaona J.-R., Allnutt T.F. \& Achard F. 2018. Combining global tree cover loss data with historical national forest cover maps to look at six decades of deforestation and forest fragmentation in Madagascar. Biological Conservation 222: 187-197. https://doi.org/10.1016/j.biocon.2018.04.008

Zimmermann A. 1920. Pars 71. Dytiscidae, Haliplidae, Hygrobiidae, Amphizoidae. In: Schenkling S. (ed.) Coleopterorum Catalogus, Volumen IV. Junk, Berlin. 
Published on: 5 October 2020

Topic editor: Nesrine Akkari

Section editor: Max Barclay

Desk editor: Pepe Fernández

Printed versions of all papers are also deposited in the libraries of the institutes that are members of the EJT consortium: Muséum national d'histoire naturelle, Paris, France; Meise Botanic Garden, Belgium; Royal Museum for Central Africa, Tervuren, Belgium; Royal Belgian Institute of Natural Sciences, Brussels, Belgium; Natural History Museum of Denmark, Copenhagen, Denmark; Naturalis Biodiversity Center, Leiden, the Netherlands; Museo Nacional de Ciencias Naturales-CSIC, Madrid, Spain; Real Jardín Botánico de Madrid CSIC, Spain; Zoological Research Museum Alexander Koenig, Bonn, Germany; National Museum, Prague, Czech Republic.

\section{Supplementary material}

Supplementary file 1. Material examined of Malagasy Bidessus Sharp, 1882.

https://doi.org/ 10.5852/ejt.2020.720.1109.2867 